\title{
KOMPARASI KINERJA KEUANGAN BANK NASIONAL DAN BANK \\ ASING TAHUN 2010-2014
}

\author{
Oleh: \\ La Subuh \\ Idah Zuhroh \\ Muhammad Faisal Abdullah \\ Fakultas Ekonomi Dan BisnisUniversitas Muhammadiyah Malang \\ Email:lasubuh7@gmail.com
}

\begin{abstract}
The purpose of this research was to know the profile of the financial performance of national banks and foreign banks and better financial performance between national bank with foreign banks. Analysis tool used was the test of normality and independent sample t-test. Research results showed that foreign banks are better than CAR aspect ratio, ROA and BOPO whereas national bank better than KAP and aspect ratio LDR. Then you coould take the conclusion that financial performance was better than foreign banks on the financial performance of national bank. Significant differences between the foreign banks and the national bank were at the ratio of $C A R, R O A$, and $L D R, B O P O$. Then that there was no significant difference in the ratio was KAP. Based on the determination of the level of health of the banks, both foreign and National Banks were are on health predicate.
\end{abstract}

Keyword: $C A R, K A P, R O A, B O P O$, and $L D R$.

\begin{abstract}
Abstrak
Tujuan penelitian ini adalah mengetahui profil kinerja keuangan bank nasional dan bank asing dan kinerja keuangan yang lebih baik antara bank nasioanl dengan bank asing. Alat analisis yang digunakan adalah uji normalitas dan independent sample t-test. Hasil penelitian menunjukan bahwa bank asing lebih baik dari aspek rasio CAR, ROA dan BOPO sedangkan bank nasional lebih baik dari aspek rasio KAP dan LDR. maka dapat di ambil kesimpulan bahwa kinerja keuangan bank asing lebih baik dari pada kinerja keuangan bank nasional. Perbedaan signifikan antara bank asing dan bank nasional berada pada RasioCAR, ROA, BOPO, dan LDR. Kemudian yang tidak ada perbedaan signifikan berada pada Rasio KAP. Berdasarkan penentuan tingkat kesehatan bank, baik Bank Asing maupun Bank Nasional berada pada predikat sehat.
\end{abstract}

Kata Kunci: CAR, KAP, ROA, BOPO dan LDR.

\section{PENDAHULUAN}

Dalam kehidupan globalisasi

yang terjadi belakangan ini, peran

bank sangat besar dalam mendorong pertumbuhan ekonomi suatu Negara. hampir semua sektor usaha, yang meliputi sektor industri, perdagangan, pertanian, perkebunan, 
jasa, dan perumahan sangat membutuhkan bank sebagai mitra dalam melakukan transaksi keuangan. Semua sektor usaha maupun individu saat ini dan masa yang akan datang tidak akan lepas dari sektor keuangan dalam mendukung kelancaran usaha. Sehingga tidak berlebihan jika bank memiliki peran sentral dalam meningkatkan pertumbuhan ekonomi.

Sebagai lembaga yangmemiliki peran sentral dalam meningkatkanpertumbuhan ekonomi suatu negara dimana bank menjalankan peran sebagai lembaga intermediasi antara pihak yang memiliki kelebihan dana (surplus unit) yang menyimpan kelebihan dananya di bank denganpihak yang kekurangan dana (defisit unit) yang meminjam dana ke bank, fungsi intermediasi bank akan berjalan optimal apabila surplus unit dan defisit unit memiliki kepercayaan kepada bank.

Tingginya persaingan industri perbankan di indonesia semakin menuntut bank untuk meningkatkan kinerjanya agar memperoleh kepercayaan masyarakat, tuntutan perbaikan kinerja di sektor perbankan ini juga sangat relevan dengan telah di bukanya integrasi ekonomi ASEAN pada tanggal 31 desember 2015 dan integrasi sektor keuangan ASEAN pada tahun 2020 yang akan membuka akses bagi bank-bank dengan kualifikasi tertentu (Qualified ASEAN Bank) untuk memperluas wilayah operasional dan memperluas pasarnya di kawasan ASEAN (Widyatmoko, 2015).

Analisis kinerja keuangan bank merupakan proses pengkajian secara kritis terhadap keuangan bank menyangkut review data, menghitung, mengukur, menginterpretasi dan memberi solusi terhadap keuangan bank pada suatu periode tertentu. Menurut UndangUndang RI Nomor 10 Tahun 1998 tanggal 10 November 1998 tentang perbankan, yang dimaksud dengan Bank adalah "badan usaha yang menghimpun dana dari masyarakat dalam bentuk simpanan dan menyalurkannya kepada masyarakat dalam bentuk kredit atau bentukbentuk lainnya dalam rangka meningkatkan taraf hidup rakyat banyak". 
Dari sudut kepemilikannya, bank dapat dibedakan menjadi: Bank Pemerintah/Bank Negara, yaitu bank yang bagian terbesar sahamnya dimilki oleh pemerintah atau negara. Bank Swasta Nasional, yaitu bank yang seluruh sahamnya dimiliki oleh pihak swasta. Bank swasta nasional ini dapat dibedakan menjadi dua golongan berdasarkan kemampuannya melakukan transaksi internasional dan transaksi valas yaitu bank devisa dan bank non devisa. Bank Asing, yaitu bank yang sahamnya dimiliki pihak asing. Bank Campuran, yaitu bank yang sebagian sahamnya dimiliki oleh pihak asing dan sebagian lagi dimiliki oleh pihak swasta nasional.

Bank yang digunakan dalam penelitian ini adalah bank nasional dan bank asing. Menurut Suyatno sebagaimana dikutip oleh Handayani (2005 : 12), bank nasional terdiri dari bank sentral dan bank umum milik negara, bank-bank milik pemerintah daerah yaitu bank-bank pembangunan daerah yang terdapat pada setiap daerah tingkat I, bankbank milik swasta nasional yaitu bank-bank seluruh sahamnya dimiliki warga negara dan atau badan-badan hukum yang peserta dan pemimpinnya terdiri atas warga negara indonesia.

Bank nasional merupakan bank yang paling banyak beredar di Indonesia, dalam praktiknya ragam produk tergantung dari status bank yang bersangkutan. Menurut stastus bank umum dibagi kedalam dua jenis yaitu bank umum devisa dan bank umum non devisa, masing-masing status memberikan pelayanan yang berbeda. Bank umum devisa misalnya memiliki jumlah layanan jasa yang paling lengkap seperti dapat melakukan kegiatan yang berhubungan dengan jasa luar negeri. Sedangkan bank umum non devisa sebaliknya tidak dapat melayani jasa yang berhubungan dengan luar negeri.

Bank asing adalah bank-bank umum swasta yang merupakan perwakilan (kantor cabang) bankbank induknya di negara asalnya. Menurut global finance database (2012) sebagaimana dikutip oleh Astuti (2015 : 2), menunjukan bahwa singapura dan indonesia merupakan negara dengan proporsi jumlah bank asing tertinggi, masing-masing mencapai 55 persen dan 52 persen. 
Filipina adalah negara dengan proporsi jumlah bank asing terendah (13 persen), dibawah Thailand (19 persen) dan Malaysia (33 persen). Kegiatan bank asing lebih dikhususkan dalam bidang-bidang tertentu dan ada larangan tertentu pula dalam melakukan kegiatannya.

Bank asing memfasilitasi akses negara penerima terhadap produk dan teknologi baru dan meningkatkan efisiensi pasar keuangan. Bank-bank asing yang masuk di indonesia pada umumnya adalah bank-bank besar dunia, seperti HSBC, Standard Chartered, Bank Of Tokyo, Citibank, Deutsche Bank. Bank-bank tersebut sudah sangat dikenal memiliki competitive advantage berupa source of fund dalam valas yang kuat, implementasi teknologi yang canggih, pengetahuan terhadap produk keuangan yang luas, serta manajemen risiko yang kuat. Penelitian yang dilakukan oleh Tan Henry (2007) mengemukakan bahwa bank asing secara khusus lebih fokus menjadi bank yang melakukan aktivitas yang menghasilkan fee based income.

Dengan masih adanya persoalan intermediasi perbankan serta kemungkinan terus berlanjutnya kegiatan spekulasi bank nasional dan bank asing yang dapat mempengaruhi perkembangan ekonomi domestik, maka penelitian ini perlu menganalisis perbandingan kinerja bank nasional dan bank asing. Dalam mengkomparasikan kinerja keuangan bank nasional dan bank asing menggunakan rasio keuangan bank. Analisis rasio keuangan bank memungkinkan manajemen untuk mengidentifikasi perubahanperubahan pokok pada trend, jumlah dan hubungan serta alasan perubahan tersebut.

Hasil analisis rasio keuangan akan membantu menginterpretasikan berbagai hubungan kunci serta kecenderungan yang dapat menjadi dasar pertimbangan mengenai potensi keberhasilan perusahaan dimasa yang akan datang dan dapat diperoleh gambaran mengenai peranan dari masing-masing kelompok bank tersebut terhadap perekonomian nasional. Untuk menganalisis rasio keuangan bank dapat diukur dengan aspek permodalan, kualitas asset, rentabilitas, dan likuiditas seperti 
telah disebutkan diatas pada pengertian kinerja keuangan.

Dimana penggunaan aspek permodalan untuk mengetahui kemampuan kecukupan modal bank dalam mendukung kegiatan bank secara efisien, aspek kualitas asset untuk menilai kondisi aset bank termasuk antisipasi atas risiko gagal bayar dari pembiayaan (credit Risk) yang akan muncul, aspek rentabilitas untuk mengetahui kemampuan bank dalam menghasilkan profit melalui operasi bank dan Aspek likuiditas untuk mengukur kemampuan bank dalam menyelesaikan kewajiban jangka pendek.

Yang menjadi pertanyaan bagaimana profil kinerja keuangan bank nasional dan bank asing serta apakah kinerja keuangan bank nasional lebih baik dibandingkan dengan kinerja keuangan bank asing?

Tujuan penelitian ini adalah mengetahui profil kinerja keuangan bank nasional dan bank asing dan kinerja keuangan yang lebih baik antara bank nasioanl dengan bank asing. Dalam penelitian ini menggunakan analisis CAEL (capital, asset, earning, dan liquidity) aspek capital diproksikan dengan capital adequacy ratio(CAR), asset diproksikan dengan kualitas aktiva produktif $(K A P)$, earning yang diproksikan dengan retrun on assets (ROA) dan rasio beban operasional terhadap pendapatan operasional (BOPO), danliquidity yang diproksikan dengan loan to deposit ratio (LDR). Berdasarkan latar belakang diatas maka penelitian ini berjudul "Komparasi Kinerja Keuangan Bank Nasional Dan Bank Asing Tahun 2010-2014”.

\section{METODE PENELITIAN}

Penelitian ini dilakukan di Bank Indonesia yaitu pada publikasi laporan keuangan bank nasional dan bank asing, Jenis penelitian yang digunakan adalah penelitian komparatif dan explanatory (penelitian penjelasan)yang diukur dengan menggunakan metode CAEL. Variabel yang digunakan dalam penelitian ini adalah capital adequacy ratio(CAR), kualitas aktiva produktif $(K A P)$,retrun on assets (ROA), rasio beban operasional terhadap pendapatan operasional $(B O P O)$, dan loan to deposit ratio (LDR). 
Populasi yang digunakan dalam penelitian ini adalah bank nasional dan bank asing dari publikasi laporan keuangan bank yang ada pada www.bi.go.id sejak tahun 2010 sampai dengan 2014, Pengambilan sampel menggunakan purposive sampling. Sumber Data dalam melakukan penelitian ini adalah data sekunder, yaitu data yang tidak diperoleh secara langsung di lapangan atau melalui laporan keuangan perbankan yang telah dipublikasikan.

Teknik pengumpulan data dalam penelitian ini diperoleh dengan menggunakan teknik dokumentasi, yaitu teknik pengumpulan data dengan cara mengumpulkan, mempelajari, dan mengolah data yang bersumber dari instansi terkait yaitu Bank Indonesia.

Teknik analisis data yang digunakan adalah sebagai berikut:

Uji normalitas, Jika Sig. (Signifikansi) atau nilai probabilitas $<0,05$, maka data berdistribusi tidak normal; dan Jika Sig. (Signifikansi) atau nilai probabilitas $>0,05$, maka data berdistribusi normal.

Uji Perbandingan dengan menggunakan uji t, Independent sample t-test merupakan teknik analisis untuk membandingkan satu variabel bebas. Teknik ini digunakan untuk menguji apakah nilai tertentu berbeda secara signifikan atau tidak dengan rata-rata sebuah sampel.

Pengujian Hipotesis, Menyusun hipotesis nol (H0) dan hipotesis alternatif $(\mathrm{Ha}), \mathrm{H} 0=\mathrm{b} 1=$ b2 $=0$, diduga tidak ada perbedaan antara rata-rata dua kelompok sampel yang tidak berhubungan. $\mathrm{Ha}=\mathrm{b} 1 \neq$ $\mathrm{b} 2 \neq 0$, diduga ada perbedaan antara rata-rata dua kelompok sampel yang tidak berhubungan. Menentukan tingkat signifikansi yaitu sebesar 0,05 ( $\mathrm{a}=0,05) \quad$ Membandingkan $\mathrm{T}$ hitung dengan $\mathrm{T}$ tabel Dengan kriteria pengujian: Ho diterima dan Ha ditolak apabila t hitung $<\mathrm{t}$ tabel artinya tidak ada perbedaan antara rata-rata dua kelompok sampel yang tidak berhubungan. Ho ditolak dan Ha diterima apabila $t$ hitung $>\mathrm{t}$ tabel artinya ada perbedaan antara rata-rata dua kelompok sampel yang tidak berhubungan.

Rumus Independent Sample t-tes:

$t=\frac{X 1-X 2}{S x-x}$

Keterangan:

$\mathrm{t}=$ nilai $\mathrm{t}$ hitung 
$\mathrm{X} 1$ = rata-rata kelompok 1

$\mathrm{X} 2$ = rata-rata kelompok 2

$\mathrm{Sx}-\mathrm{X}=$ standard error kedua

kelompok

\section{Uji normalitas}

Berikut adalah hasil Uji Normalitas dengan Two-Sample Kolmogorov Smirnov Bank Asing dan Bank Nasional tahun 2010-2014.

\section{PEMBAHASAN}

\section{Tabel 1. Test Statistics ${ }^{a}$}

\begin{tabular}{llccccc} 
& & CAR & KAP & ROA & BOPO & LDR \\
\hline $\begin{array}{llcccc}\text { Most Extreme } \\
\text { Differences }\end{array}$ & Absolute & .480 & .120 & .383 & .331 & .400 \\
\cline { 2 - 6 } & Positive & .480 & .120 & .383 & .023 & .400 \\
\cline { 2 - 6 } & Negative & .000 & -.080 & -.011 & -.331 & -.086 \\
\hline Kolmogorov-Smirnov Z & 1.833 & .458 & 1.462 & 1.266 & 1.528 \\
\hline Asymp. Sig. (2-tailed) & .002 & .985 & .028 & .081 & .019 \\
\hline
\end{tabular}

Grouping Variable: Jenis_Bank

Sumber: Data diolah, 2016

Hasil uji normalitas CAR dengan Two-Sample KolmogorovSmirnov terlihat pada test statistics nilai $\mathrm{Z}=1,833(\mathrm{P}>0,05)$. Dari sini menunjukan bahwa data CAR berdistribusi normal.

Hasil uji normalitas KAP dengan Two-Sample KolmogorovSmirnov terlihat pada test statistics $\mathrm{Z}$ $=0,458 \quad(\mathrm{P}>0,05) . \quad$ Dari sini menunjukan bahwa data KAP berdistribusi normal.

Hasil uji normalitas ROA dengan Two-Sample KolmogorovSmirnov terlihat pada test statistics $\mathrm{Z}$ $=1,462 \quad(\mathrm{P}>0,05) . \quad$ Dari sini menunjukan bahwa data ROA berdistribusi normal.

Hasil uji normalitas BOPO dengan Two-Sample KolmogorovSmirnov terlihat pada test statistics nilai $\mathrm{Z}=1,266(\mathrm{P}>0,05)$. Dari sini menunjukan bahwa data BOPO berdistribusi normal.

Hasil uji normalitas LDR dengan Two-Sample KolmogorovSmirnov terlihat pada test statistics nilai $\mathrm{Z}=1,528(\mathrm{P}>0,05)$. Dari sini menunjukan bahwa data LDR berdistribusi normal.

Uji independent samples test, Berikut adalah hasil uji beda Grup Statistik 
Bank Asing dengan Bank Nasional

tahun 2010-2014.

\section{Tabel 2. Group Statistics}

\begin{tabular}{llllll}
\hline \multirow{2}{*}{ CAR } & Jenis_Bank & $\mathrm{N}$ & Mean & Std. Deviation & Std. Error Mean \\
\cline { 2 - 6 } & Bank_Asing & 25 & 27.1600 & 17.43483 & 3.48697 \\
\cline { 2 - 6 } KAP & Bank_Nasional & 35 & 16.6857 & 3.38484 & .57214 \\
\cline { 2 - 6 } & Bank_Asing & 25 & 1.0800 & 1.65630 & .33126 \\
\hline \multirow{2}{*}{ ROA } & Bank_Nasional & 35 & .8857 & .90005 & .15214 \\
\cline { 2 - 6 } & Bank_Asing & 25 & 2.6000 & 1.29099 & .25820 \\
BOPO & Bank_Nasional & 35 & 1.7143 & 1.01667 & .17185 \\
\cline { 2 - 6 } & Bank_Nasional & 35 & 81.1143 & 6.09132 & 1.94679 \\
\hline \multirow{2}{*}{ LDR } & Bank_Asing & 25 & $1.1568 \mathrm{E} 2$ & 74.94260 & 14.98852 \\
\cline { 2 - 6 } & Bank_Nasional & 35 & 81.0286 & 12.55221 & 2.12171 \\
\hline
\end{tabular}

Sumber: Data diolah, 2016

Hasil data statistik

menunjukkan bahwa nilai rata-rata

CAR Bank Asing lebih tinggi dibanding dengan nilai rata-rata

CAR bank nasional. Nilai rata-rata

CAR Bank Asing adalah 27.1600 sedangkan Bank Nasional memiliki nilai rata-rata CAR sebesar 16.6857 . Nilai CAR Bank Asing yang lebih tinggi dari Bank Nasional menunjukkan bahwa kemampuan Bank Asing memikul resiko kerugian yang lebih baik dan mengindikasikan semakin sehat permodalannya dari Bank Nasional.

Hasil data statistik menunjukkan bahwa nilai rata-rata KAP Bank Asing lebih tinggi dibanding dengan nilai rata-rata KAP bank nasional. Nilai rata-rata KAP Bank Asing adalah 1.0800 sedangkan Bank Nasional memiliki nilai rata-rata KAP sebesar 0.8857 . Nilai KAP Bank Asing yang lebih tinggi dari Bank Nasional menunjukkan bahwa kemampuan kualitas aktiva produktif Bank Nasional lebih sehat dibandingkan dengan Bank Asing.

Hasil data statistik menunjukkan bahwa nilai rata-rata ROA Bank Asing lebih tinggi dibanding dengan nilai rata-rata ROA bank nasional. Nilai rata-rata ROA Bank Asing adalah 2.6000 sedangkan Bank Nasional memiliki nilai rata-rata ROA sebesar 1.7143 . Nilai ROA Bank Asing yang lebih tinggi dari Bank Nasional menunjukkan bahwa kemampuan Bank Asing dalam menghasilkan 
laba dengan menggunakan asetnya lebih tinggi dari Bank Nasional.

Hasil data statistik menunjukkan bahwa nilai rata-rata BOPO Bank Asing lebih rendah dibanding dengan nilai rata-rata BOPO bank nasional. Nilai rata-rata BOPO Bank Asing adalah 76.6000 sedangkan Bank Nasional memiliki nilai rata-rata $\mathrm{BOPO}$ sebesar 81.1143. Nilai BOPO Bank Asing yang lebih rendah dari Bank Nasional menunjukkan bahwa semakin efisien biaya operasional yang dikeluarka bank Asing dibandingkan Bank Nasional.
Hasil data statistik menunjukkan bahwa nilai rata-rata LDR Bank Asing lebih tinggi dibanding dengan nilai rata-rata LDR bank nasional. Nilai rata-rata LDR Bank Asing adalah 115.6800 sedangkan Bank Nasional memiliki nilai rata-rata LDR sebesar81.0286. Nilai LDR Bank Asing yang lebih tinggi dari Bank Nasional menunjukkan bahwa rendahnya likuiditas Bank Asing dibandingkan dengan Bank Nasional. sehingga kemungkinan Bank Asing dalam kondisi bermasalah semakin besar.

Tabel 3. Independent Samples Test

\begin{tabular}{llrrrrr}
\hline & & \multicolumn{5}{c}{ t-test for Equality of Means } \\
\cline { 3 - 7 } & & \multicolumn{1}{c}{$\mathrm{t}$} & $\mathrm{df}$ & $\begin{array}{c}\text { Sig. (2- } \\
\text { tailed) }\end{array}$ & Lower & Upper \\
\hline \multirow{2}{*}{ CAR } & Equal variances assumed & 3.475 & 58 & .001 & 4.44064 & 16.50793 \\
& Equal variances not assumed & 2.964 & 25.297 & .007 & 3.20104 & 17.74753 \\
\hline \multirow{2}{*}{ KAP } & Equal variances assumed & .585 & 58 & .561 & -.47083 & .85940 \\
& Equal variances not assumed & .533 & 34.121 & .597 & -.54642 & .93499 \\
\hline ROA & Equal variances assumed & 2.972 & 58 & .004 & .28909 & 1.48234 \\
& Equal variances not assumed & 2.856 & 43.893 & .007 & .26059 & 1.51084 \\
\hline BOPO & Equal variances assumed & -2.208 & 58 & .031 & -8.60678 & -.42179 \\
& Equal variances not assumed & -2.050 & 37.247 & .047 & -8.97557 & -.05300 \\
\hline \multirow{2}{*}{ LDR } & Equal variances assumed & 2.692 & 58 & .009 & 8.88480 & 60.41806 \\
& Equal variances not assumed & 2.289 & 24.964 & .031 & 3.47199 & 65.83087 \\
\hline
\end{tabular}

\section{Sumber: Data diolah}

\section{Uji Hipotesis}

Hasil perhitungan dengan menggunakan uji Independent Sample T-Test rasio CAR menunjukan bahwa ada perbedaan yang signifikan terhadap kinerja keuangan Bank Asing dan Bank Nasional, artinya H0 ditolak dan H1 diterima. Hal ini ditunjukkan dengan nilai signifikansi sebesar $0.001<0.05$ adanya perbedaan signifikan ini menunjukan bahwa kemampuan 
bank asing dalam mengantisipasi kebutuhan akan tersedianya dana sendiri guna pertumbuhan usaha serta memikul resiko kerugian yang timbul dalam menjalankan usahanya lebih baik dibandingkan dengan bank nasional.

Kriteria penilaian tingkat kesehatan bank yang ditetapkan oleh Bank Indonesia Rasio CAR sebesar $8 \%$, sebagaimana dalam ketentuan yang berlaku jika nilai CAR semakin besar maka akan semakin baik karena bank mampu menyediakan modal dalam jumlah yang besar sehingga rasio CAR yang dimiliki oleh Bank Asing dan Bank Nasional dikategorikan sehat.

Hasil perhitungan dengan menggunakan uji Independent Sample T-Test rasio KAP menunjukan bahwa tidak ada perbedaan yang signifikan terhadap kinerja keuangan Bank Asing dan Bank Nasional, artinya H0 diterima dan H1 ditolak. Hal ini ditunjukkan dengan nilai signifikansi sebesar $0.561>0.05$.

Tidak adanya perbedaan signifikan ini menunjukan bahwa baik Bank Asing maupun Bank Nasional sama-sama memiliki kemampuan yang baik dalam penanaman dana bank dalam bentuk kredit, surat berharga, penyertaan dan penanaman lain untuk memperoleh penghasilan sebagaimana dalam ketentuan yang berlaku jika nilai KAP semakin kecil maka akan semakin meningkat kualitas aktiva produktif karena bank bertambah kemampuan kualitas aktiva produktif yang dimiliki bank untuk menutupi aktiva produktif yang diklasifikasikan berupa kredit yang diberikan oleh bank, sehingga rasio KAP yang dimiliki oleh Bank Asing dan Bank Nasional dikategorikan sehat.

Hasil perhitungan dengan menggunakan uji Independent Sample T-Test rasio ROA menunjukan bahwa ada perbedaan yang signifikan terhadap kinerja keuangan Bank Asing dan Bank Nasional, artinya H0 ditolak dan H1 diterima. Hal ini ditunjukkan dengan nilai signifikansi sebesar $0.004<0.05$ adanya perbedaan signifikan ini menunjukan bahwa Bank Asing memiliki kemampuan yang lebih baik dalam mengahasilkan laba dengan menggunakan asetnya dibandingkan Bank Nasional. 
Kriteria penilaian tingkat kesehatan bank yang ditetapkan oleh Bank Indonesia sebesar 0,5\% samapi dengan $1,25 \%$. sebagaimana dalam ketentuan yang berlaku jika nilai ROA semakin besar (>1.25\%) maka akan semakin baik karena bank mampu mengelola asset secara efektif dan efisien dalam memperoleh laba bersih, sehingga rasio ROA yang dimiliki oleh Bank Asing dan Bank Nasional dikategorikan sehat.

Hasil perhitungan dengan menggunakan uji Independent Sample T-Test rasio $\mathrm{BOPO}$ menunjukan bahwa ada perbedaan yang signifikan terhadap kinerja keuangan Bank Asing dan Bank Nasional, artinya H0 ditolak dan H1 diterima. Hal ini ditunjukkan dengan nilai signifikansi sebesar $0.031<0.05$ adanya perbedaan signifikan ini menunjukan bahwa Bank Asing memiliki kemampuan yang lebih baik dalam mengendalikan biaya operasional terhadap pendapatan operasional sehingga semakin efisien biaya operasional yang dikeluarka Bank Asing dibandingkan dengan Bank Nasional.
Kriteria penilaian tingkat kesehatan bank yang ditetapkan oleh Bank Indonesia Rasio BOPO sebesar 94\% sampai dengan 96\%. sebagaimana dalam ketentuan yang berlaku jika nilai BOPO Semakin kecil berarti semakin efisien biaya operasional yang dikeluarka bank, sehingga tingkat efisiensi bank akan semakin tinggi. Maka rasio BOPO yang dimiliki oleh Bank Asing dan Bank Nasional dikategorikan sehat.

Hasil perhitungan dengan menggunakan uji Independent Sample T-Test rasio LDR menunjukan bahwa ada perbedaan yang signifikan terhadap kinerja keuangan Bank Asing dan Bank Nasional, artinya H0 ditolak dan H1 diterima. Hal ini ditunjukkan dengan nilai signifikansi sebesar $0.009<0.05$ adanya perbedaan signifikan ini menunjukan bahwa rendahnya likuiditas Bank Asing dibandingkan dengan Bank Nasional. sehingga kemungkinan Bank Asing dalam kondisi bermasalah semakin besar. Sebagaimana dalam ketentuan yang berlaku jika nilai LDR Semakin besar mengindikasikan bank itu semakin agresif likuiditasnya, sebaliknya semakin kecil rasio ini 
juga semakin besar dana pihak ketiga yang tidak digunakan untuk penempatan ke kredit (banyak dana menganggur) atau menunjukan bahwa pertumbuhan dana pihak ketiga yang diterima lebih besar dibandingkan pertumbuhan kredit yang diberikan. Maka rasio LDR yang dimiliki oleh Bank Asing dan Bank Nasional dikategorikan sehat.

\section{PENUTUP}

\section{Kesimpulan}

\begin{abstract}
Berdasarkan hasil penelitian dan pembahasan mengenai komparasi kinerja keuangan bank nasional dan bank asing tahun 20102014 pada BAB sebelumnya, terlihat bahwa Bank Asing lebih baik dari aspek rasio CAR, ROA dan BOPO sedangkan Bank Nasional lebih baik dari aspek rasio KAP dan LDR. maka dapat di ambil kesimpulan bahwa Kinerja Keuangan Bank Asing Lebih Baik dari pada Kinerja Keuangan Bank Nasional.
\end{abstract}

\section{Rasio Capital Adequacy}

Ratio (CAR), Nilai rata-rata CAR

Bank Asing sebesar 27.16 lebih tinggi dibandingkan Bank Nasional yang memiliki nilai rata-rata CAR sebesar 16.69. Nilai CAR Bank
Asing yang lebih tinggi dari Bank Nasional menunjukkan bahwa kemampuan Bank Asing memikul resiko kerugian yang lebih baik dan mengindikasikan semakin sehat permodalannya dari Bank Nasional.

Rasio Kualitas Aktiva Produktif (KAP), Nilai rata-rata KAP Bank Asing adalah 1.08 sedangkan Bank Nasional memiliki nilai ratarata KAP sebesar 0.89. Nilai KAP Bank Asing yang lebih tinggi dari Bank Nasional menunjukkan bahwa kemampuan kualitas aktiva produktifBank Nasional lebih sehat dibandingkan dengan Bank Asing.

Return On Asset (ROA), Nilai rata-rata ROA Bank Asing sebesar 2.60 sedangkan Bank Nasional memiliki nilai rata-rata ROA sebesar 1.71. Nilai ROA Bank Asing yang lebih tinggi dari Bank Nasional menunjukkan bahwa kemampuan Bank Asing dalam menghasilkan laba dengan menggunakan asetnya lebih tinggi dari Bank Nasional.

Rasio Beban Operasional Terhadap Pendapatan Operasional (BOPO), Nilai rata-rata BOPO Bank Asing sebesar 76.60 sedangkan Bank Nasional memiliki nilai rata-rata 
BOPO sebesar 81.11. Nilai BOPO Bank Asing yang lebih rendah dari Bank Nasional menunjukkan bahwa semakin efisien biaya operasional yang dikeluarka bank Asing dibandingkan Bank Nasional.

Loan to Deposit Ratio (LDR), Nilai rata-rata LDR Bank Asing adalah 115.68 sedangkan Bank Nasional memiliki nilai rata-rata LDR sebesar 81.03. Nilai LDR Bank Asing yang lebih tinggi dari Bank Nasional menunjukkan bahwa rendahnya likuiditas Bank Asing dibandingkan dengan Bank Nasional. sehingga kemungkinan Bank Asing dalam kondisi bermasalah semakin besar.

Berdasarkan hasil uji beda Independent Sample T-Test Bank Asing dengan Bank Nasional tahun 2010-2014, Perbedaan signifikan antara bank asing dan bank nasional berada pada Rasio CAR, ROA, BOPO, dan LDR. Kemudian yang tidak ada perbedaan signifikan berada pada Rasio KAP. Berdasarkan penentuan tingkat kesehatan bank, baik Bank Asing maupun Bank Nasional berada pada predikat SEHAT. Hal ini dapat dilihat dari aspek rasio keuangan bank yang telah memenuhi standar kriteria yang telah ditetapkan oleh Bank Indonesia.

\section{Saran}

Berdasarkan hasil pengujian ditemukan bahwa Bank Asing lebih baik dari aspek rasio CAR, ROA dan BOPO sedangkan Bank Nasional lebih baik dari aspek rasio KAP dan LDR, maka akan diberikan saransaran yaitu sebagai berikut:

Bank Nasional perlu meningkatkan kinerja keuangan bank pada periode mendatang dalam hal kesehatan permodalan yaitu capital adequacy ratio dan rentabilitas yaitu return on asset dan biaya operasional terhadap pendapatan operasional.

Pemerintah melakukan regulasi dan pengawasan yang dapat mendorong kemajuan perbankan di indonesia dalam menghadapi persaingan bank-bank asing.Bagi Peneliti Selanjutnya, diharapkan mengembangkanlebih lanjut model penelitian agar dapat memberikan kontribusi yang lebih mendalam.

\section{DAFTAR PUSTAKA}

Abdullah, M. Faisal, 2003, Manajemen Perbankan; Edisi Pertama, UMM Press, Malang. 
Astuti, Hikmah Dwi., 2015. Analisis Perbandingan Kinerja Bank Asing Dan Bank Nasional Dengan Menggunakan Rasio Keuangan : Jurnal Magister Manajemen, Vol 01, No 1 : 2021.

Angel, Christania Graciella., 2014. Analisis perbandingan kinerja pada bank nasional dan bank asing dengan menggunakan analisis rasio keuangan.

Handayani, Puspita Sari., 2005. Analisis perbandingan kinerja bank nasiobnal, bank campuran dan bank asing dengan menggunakan rasio keuangan.

Henry, Tan., 2007. Analisis Perbedaan Kinerja Keuangan Antara Bank Asing dan Bank Umum Di Indonesia : Journal of Money, Credit and Banking, 13 (8).

Ismail, 2011, Manajemen Perbankan; Edisi Pertama, Kencana Prenada Media Group, Jakarta.

Kasmir, 2008, Bank dan Lembaga Keuangan Lainnya; Edisi Revisi 8, PT RajaGrafindo Persada, Jakarta.
Kasmir, 2012, Manajemen Perbankan; Edisi Revisi 11, PT RajaGrafindo Persada, Jakarta.

Lampiran Surat Edaran bank Indonesia No 6/23/DPNP Tanggal 31 Mei 2004.

Peraturan Bank Indonesia Nomor 6/10/PBI/2004 Tentang Sistem Penilaian Tingkat Kesehatan Bank Umum.

Surat Edaran Bank Indonesia No 6/23/DPNP Tanggal 31 Mei 2004 Perihal Sistem Penilaian Tingkat Kesehatan Bank Umum.

Sugiyono, 2013, Metode Penelitian Kuantitatif, Kualitatif, Dan Kombinasi; Cetakan Ke 4, Alfabeta, Bandung.

Taswan, 2010, Manajemen Perbankan; Edisi II, UPP STIM YKPN, Yogyakarta.

Widyatmoko., Arga., 2015. Analisis efisiensi perbankan di Indonesia dengan pendekatan data envelopment analysis : jimfeb.

www.bi.go.id, Di Akses pada tanggal 27 maret 2016. Pukul 24.00 WIB. 